\title{
INDIA AND THE CRISIS IN KASHMIR
}

\section{Sumit Ganguly and Kanti Bajpai}

With the end of the Cold War, regional security problems have become paradigmatic. Whereas they were once seen primarily as functions of - or in some cases even epiphenomenal to-superpower rivalry, they are now central. International security is largely regional security in the absence of a global strategic conflict. As a result, attention has shifted from consideration of the global strategic balance to local conflict. Broadly, these local conflicts are a function of two factors: regional distributions of power but also animosities rooted in ethnic, religious, territorial, and irredentist contestation. The problem for policy is that the latter factors are more intractable than the former; distributions of power are more amenable to management than are animosities based on, or evocative of seemingly old quarrels and fears. This article focuses on one of the most costly and dangerous of these animosities, namely, the Indian and Pakistani contest over the divided state of Kashmir.

\section{Kashmir and the New Arc of Crisis}

From Eastern Europe and the former Soviet republics in the Baltic and Central Asia, through Turkey, Pakistan, and Afghanistan, to China and India there exists a giant arc of crisis typified by mutually entangling interstate and intrastate rivalries. This arc is at once the most unstable and the most militarized space on earth. It includes three front-rank military powers (Russia, China, and India) and several middle powers (Poland, Czechoslovakia, Turkey, Israel, Egypt, Iraq, Iran, and Pakistan). The future of international security will rest in large part on how instability and militarization are managed here.

Sumit Ganguly is Professor of Political Science, Hunter College, CUNY, and currently Fellow at the Woodrow Wilson International Center for Scholars, Washington, D.C. Kanti Bajpai is Resident Fellow at the Rajiv Gandhi Institute for Contemporary Studies, Rajiv Gandhi Foundation, New Delhi. Sumit Ganguly wishes to acknowledge funding for research on which this study is based from the U.S. Institute of Peace, Washington, D.C.

(C) 1994 by The Regents of the University of California 
Within this new arc of crisis, the Indian-Pakistani contest over Kashmir has resurged since the late 1980 s. $^{1}$ Kashmir is in many ways representative of the long-term instabilities in the arc-a mix of ethnic, religious, and territorial battles; irredentism; hypernationalism; and economic reform and turbulence leading to protracted interstate and intrastate conflict. Kashmir is also representative of the context against which these instabilities will arise and play themselves out: a context featuring conventional and even nuclear weapons proliferation, crises of internal political authority, multilevel minority problems in multiethnic states, separatist and state violence, internal and international migration, and economic reform.

Within months of the partition of the Subcontinent in 1947, India and Pakistan went to war over Kashmir. The war ended with the division of the province between the two antagonistic, postcolonial states but the Kashmiris continued to see themselves as one people. Professing different faiths-Islam, Hinduism, and Buddhism - the three religious subcommunities of Kashmir historically have lived in peace with one another. At partition, a Hindu ruled over the predominantly Muslim population. While Muslim Kashmiris are a majority on both sides of the line of division, there are areas of Hindu and Buddhist numerical predominance in Indian Kashmir (e.g., Jammu and Leh districts, respectively). Territorially, most of Kashmir is in Indian hands including the famous Vale of Kashmir. This ethnic, religious, and territorial division has given rise to irredentist claims on both sides. However, a substantial portion of Kashmiri opinion favors a third option: independence from both India and Pakistan.

For the two countries, the conflict over Kashmir is less a contest over strategic ground or resources as over competing visions of nationalism and statebuilding. For India, Kashmir is symbolic of secular nationalism and statebuilding and of the possibility of a Muslim-majority area choosing to live and prosper within a Hindu-majority country. For Pakistan, Kashmir is symbolic of the impossibility of secular nationalism in the region and thus of the need for a Muslim homeland in the northwestern corner of the Subcontinent. Indian and Pakistani competition over Kashmir has resulted in two wars (1948 and 1965) and was the scene of fighting in the 1971 war over East Pakistan. Thus, apart from the Arab-Israeli conflict over Palestine, Kashmir has occasioned the most protracted and militarized regional dispute in the post-1945 world.

This protracted dispute must be set against a complicated and fraught context. The two states involved have the fourth and seventh largest armed

1. A recent volume of essays on Kashmir is Perspectives on Kashmir: The Roots of Conflict in South Asia, Raju Thomas, ed. (Boulder, Colo.: Westview, 1992). See also M. J. Akbar, Kashmir: Behind the Vale (New Delhi: Penguin Books India for Viking, 1991), and Balraj Puri, Kashmir: Towards Insurgency (New Delhi: Orient Longman, 1993). 
forces in the world and are incipient nuclear powers. Even as they confront the Kashmir problem, both are faced with crises of internal political authority and institutional decay. At the very moment that both need legitimate authority and strong institutions to cope with the dissatisfactions of ethnic, religious, and linguistic minorities, they are beset instead by a growing questioning of political authority and a weakening of institutions. Both countries possess weak state structures and strong coercive apparatuses; they are classic weak-strong states. ${ }^{2}$

As weak-strong states, they face a minorities problem that exists at two, even three levels and that defies easy answers. Thus, some groups are minorities nationally yet majorities in certain areas or provinces. One putative solution to these multilevel minority problems is a combination of democracy and federalism. Both states have been both democratic and federal, India more so than Pakistan, yet neither has succeeded in solving their two- and three-level minority problems. At least two consequences of this failure have been the spread of terrorism and internal migration; terrorism in Sind, Punjab, and Kashmir have led to internal migration as an escape from conflict. Finally, as India and Pakistan struggle to deal with security problems, they face severe economic troubles-internal and external deficits, low rates of economic growth, high inflation, poverty, and population increase-and the challenges of drastic economic reform.

What are the implications of the crisis for New Delhi, and how has the Indian government attempted to manage the Kashmir problem? What are its options now? A brief sketch of the causes of the present Kashmiri separatism is necessary before we proceed to grapple with these questions.

\section{India's Problem in Kashmir}

The Kashmir problem has both domestic and bilateral causes. Internally, it is related to the failures as well as the successes of Indian politics. Externally, Kashmir must be linked to the larger Subcontinental quarrel between India and Pakistan.

\section{Internal Causes: Institutional Failures, Mobilizational Successes}

Kashmir reflects the growing and larger crisis of India's political institutions. Their decay over the past two decades has included the steady organizational decline of the once-dominant Congress Party, the politicization of the civil services and judiciary, the reliance on the military to restore public order, and

2. This usage draws on Suzanne and Lloyd Rudolph's conception of the "strong-weak" state. See their In Pursuit of Lakshmi: The Political Economy of the Indian State (Delhi: Orient Longman, 1987). 
the overall lack of probity in public life. Moreover, from the early 1970s governments became increasingly centralized, resulting in conflicts between the central government and emerging elites in different parts of India that frequently ended in the dismissal or subversion of legally constituted state governments. Demands for state-level autonomy, often portrayed as "threats to national integrity," provided a justification for the imposition of central rule, which further alienated local elites and populations and added to provincial resentment. Kashmir, thus, has to be seen as part of this broader dialectic of Indian politics.

Simultaneously, and paradoxically, the present Kashmir crisis is related to the successes of the Indian system. The demands for autonomy in Punjab, Kashmir, and the northeastern states were expressive of the quickening and widening of political mobilization and participation. Autonomist demands reflected a relatively vibrant, open, and dynamic civil society reacting against the excessive centralization of state power. From Mahatma Gandhi's leadership of the Congress in the 1920s, India had undergone a gradual but significant expansion in political mobilization and participation. After independence, minorities and other disadvantaged groups still were frequently impeded from effective participation in the political system, but with growing access to education and the media and with greater social and physical mobility, hitherto disenfranchised or marginalized groups pressed to enter the political arena and could no longer be counted on to behave in predictable waysto the alarm of dominant power centers in New Delhi and state capitals.

The origins of the present Kashmir crisis must be set against this nationwide process of political mobilization and reaction. Whereas Kashmiris of Sheikh Abdullah's generation had their quarrels with New Delhi, a combination of state largesse, political repression, and political quiescence served to limit resistance to the central government. The generation of the 1980s was different, at least in part due to the mobilizational and participative successes of the Indian political system. Thus, despite Sheikh Abdullah's return to politics in 1975 and the first unblemished election in Kashmir in 1977, the early 1980s saw a growing turbulence in the politics of the state. After Sheikh's death in 1983, leadership passed to his son, Faroukh, who lacked his father's standing and charisma but inherited popular support and legitimacy. The central government, determined to increase its influence, particularly after the death of Indira Gandhi in 1984, steadily undermined Faroukh's position. His government was dismissed in 1984 and central rule imposed. An earlier generation of Kashmiris might grudgingly have accepted the government's dismissal. The new generation, better educated and more conscious of its political rights, proved less malleable.

Yet, young Kashmiris would not have turned to violence even now if New Delhi had acted with greater restraint and political subtlety. In 1986 a mar- 
riage of political convenience was fashioned between the ruling Congress Party and Faroukh's National Conference. Whatever the advantages of the alliance, in Kashmiri eyes Faroukh became an adjunct of the Congress Party. The little political legitimacy Faroukh possessed disintegrated in the 1987 state elections when the Congress-National Conference alliance was perceived to have engaged in electoral fraud. This apparent hijacking of the political process blocked off the last avenue of lawful political protest for dissatisfied residents of Kashmir Valley. Politically aroused but frustrated young men and women were increasingly drawn to incipient separatist and insurgent movements, ranging from the largely secular Jammu and Kashmir Liberation Front (JKLF) to the more religiously oriented and pro-Pakistani Hizb-ul-Mujahideen (HUM), which sent their recruits across the border to Pakistan where they were provided with training, organization, and weaponry.

\section{External Cause: The Quarrel over Nation-Building}

The problems of Kashmir stem from external as well as internal causes; the Kashmiri quarrel has been assimilated into the larger India-Pakistan quarrel over nation-building and regional order. We shall not summarize the history of the multilateral as well as bilateral negotiations over Kashmir since 1947. Suffice it to say that in the end neither India nor Pakistan was able to concede much ground. The intractability of their respective positions stemmed not so much from the strategic location of Kashmir as from the significance of the dispute for nation-building. Indian decision-makers tended to see Kashmir through the prism of secular nationalism as the basis for nation-building. If Kashmir were allowed to secede because of its Muslim-majority population, Indian leaders doubted that the idea and practice of secularism could survive, indeed, that India could survive. Conversely, Pakistan tended to see Kashmiri accession as integral to its Islamic identity. If a Muslim-majority area contiguous to Pakistan remained in India, the original justification for a Muslim state would be difficult to sustain. Thus, while two wars have added layers of political and emotional commitment to the Kashmir dispute, at base what is involved is a difference over the constitutive principles of nationbuilding and, by extension, of regional order.

\section{What the Kashmir Crisis Means for India}

The Kashmir crisis has serious implications for India. At the domestic level, it has been and will continue to be consequential for secularism, democracy, federalism, and nationalism-the four pillars of India's political structure. Kashmir is also consequential for India's international relations. 
First, and perhaps most important, the direction in which the crisis progresses and is sought to be resolved will have serious consequences for Indian secularism, which is under increasing attack from right-wing Hindu nationalist organizations. In part, this attack draws inspiration from the protracted conflicts in Kashmir and Punjab. The Hindu right argues that the origins and continuation of separatist conflict (and religious violence) can be traced to "Nehruvian secularism." In its view, the solution to separatism is not to refurbish post-independence India's "artificial" secularism but to construct an "organic" secularism built on the "natural" tolerance of Hinduism. The Hindu right apart, there is widespread feeling that the "old" secularism needs to be rethought and perhaps even replaced. While a debate over secularism is probably inescapable and not necessarily deleterious in the long run, it is clear that it will be sharp and divisive and will have to be conducted in the midst of ethnic and religious violence.

Second, the continuing deployment of the various paramilitary units as well as the army is pernicious for Indian democracy. The inordinate reliance on the army to quell civil disorder throughout India has already become a subject of concern and debate, ${ }^{3}$ and thoughtful commentators have sounded the tocsin about the dangers to the army's apolitical tradition. The deployment and continued use of force within Kashmir simply exacerbates this broader problem. Ill-suited to internal security duties, the largely unblemished image of the Indian Army is being tarnished as accusations of military brutality mount. Whatever the truth of these charges, they are bound to have a demoralizing effect on the professional military with all the attendant dangers for its view of politics and civilian institutions. ${ }^{4}$

Third, the crisis poses a direct challenge to Indian federalism. Kashmiri militants have made clear their view of the desirability and credibility of Indian federalism: seemingly no reform or amendment will satisfy. On the other side, the Hindu rightists have demanded revocation of the special status conferred on Kashmir under Article 370 of the Indian Constitution. Abrogating Article 370, among other things, would permit non-Kashmiris to purchase immovable property in Kashmir, thereby opening up the possibility of migration from other parts of India. In effect, the demographic composition of the state could be altered with non-Muslims settling in the Valley. Thus far, New Delhi has firmly resisted any formal change in Kashmir's special status.

3. Lt. Gen. Gurbir Mansingh, formerly of the Indian Army, has suggested that up to $60 \%$ of the army in recent years has been deployed to deal with internal problems. His remarks were made at a talk entitled "Security in South Asia in the Post-Cold War Era," delivered at the Program in Arms Control, Disarmament, and International Security, University of Illinois, October 1992.

4. See Stephen P. Cohen, The Indian Army: Its Contribution to the Development of a Nation, 2nd ed. (New Delhi: Oxford University Press, 1990), esp. epilogue. 
Between the militants and the Hindu extremists, there is widespread though varying dissatisfaction with the practice, if not the provisions of Indian federalism. Most Indian states want to keep federalism but would like to amend its provisions or reform its practice. At the same time, there is little doubt that they would resent any move to further enhance the special status of Kashmir (or Punjab) unless this was accompanied by negotiations for a new federal compact sensitive to their concerns. This raises the possibility in the future of a highly differentiated federal structure, with customized arrangements for individual states or groups of states-not impossible or undesirable, but surely a political enterprise of daunting proportions.

Fourth, the crisis is forcing a re-examination of the constitutive principles of Indian nationalism. Since independence, rhetoric aside, Indian governments have sought to promote various versions of what might be called homo indicus, a homogeneous, interchangeable, modern Indian who is rational, secular, and whose first loyalty is to the central government. Successive governments have seen subnational demands for greater autonomy as threats to India's cohesion and integrity. However, the problems in Kashmir and Pun$\mathrm{jab}$ are forcing attention to the need for a new nationalism, one which is comfortable with multiple loyalties and which garners loyalty to the center precisely because the center helps expand the cultural and political space available to people of diverse faiths, languages, and ethnicities. While such a nationalism is healthy, governments will find it difficult to accommodate this alternative vision of the relationship between citizen and state, which goes against the grain of nationalism over the past two centuries.

Finally, Kashmir will continue to affect India's international relations as the volatile situation in the Kashmir Valley and Pakistan's support of the insurgents raises the possibility of inadvertent or even advertent war. Aggressive Indian Army patrolling and hot pursuit of insurgents might destabilize the Line of Control. Local firefights might escalate to wider engagements even though neither side may want that. Since the 1971 war, both sides have moved increasingly toward "offensive defense" strategies. ${ }^{5}$ As both India and Pakistan are incipient nuclear weapons states, the dangers of nuclear escalation should not be viewed as entirely chimerical. The decision to fight might also be more deliberate than the above scenario suggests. If the insurgency grows and Pakistan's role deepens, New Delhi may fear that Islamabad will attempt to make a grab for Kashmir in the hope that a quick incursion combined with widespread internal insurrection would wrest the state from India despite Indian military superiority. Thus, New Delhi may

5. On Pakistani notions of offensive defense, see Stephen P. Cohen, The Pakistan Army (Berkeley: University of California Press, 1984), pp. 144-47. On India's move toward offensive defense, see George Tanham, "Indian Strategic Culture," Washington Quarterly 15 (Winter 1992), pp. 129-42. 
calculate that a carefully planned war might be worthwhile to "teach Pakistan a lesson" or to "finish the job of 1971."

In any case, whether war is inadvertent or advertent, tactical or strategic, successful or unsuccessful, quick or protracted, it would be costly - not just domestically in terms of direct human, economic, and military losses, but internationally as well. India's relations with the West, Japan, Russia, and China would suffer, with potentially severe consequences for the Indian economy and Indian security. A war over Kashmir would also harm India's relations with the Arab world as well as the emergent states of Central Asia. States as diverse as Saudi Arabia and Iran have already expressed their displeasure with India's handling of the Kashmir crisis. In the future they may well choose to go beyond verbal representations to impose material costs. ${ }^{6}$

India's internal fight against the militants would also be costly internationally. Human rights violations in Kashmir in the course of prosecuting the fight against the insurgency may threaten India's ability to obtain multilateral and bilateral assistance. Human rights organizations such as Amnesty International and Asia Watch issue regular reports on the situation in Kashmir, and multilateral donors like the International Monetary Fund and the World Bank, in the light of these reports, could become increasingly interventionist. The IMF has already suggested on at least one occasion that it might tie assistance to reductions in defense spending. Similar concerns are also being voiced at the bilateral level. Two of India's major aid donors, West Germany and Japan, have expressed concerns about India's levels of defense spending as well as its refusal to sign the nuclear Non-Proliferation Treaty (NPT). All of these may in time be willing to raise their voices on human rights.

The United States, India's most important trading partner, has already expressed concern over India's human rights record in Kashmir. President Clinton's reference to Kashmir in his U.N. speech, his remarks to Pakistani Ambassador Maleeha Lodhi to the effect that the U.S. shared Pakistan's concern over human rights, and Assistant Secretary of State Robin Raphel's various comments in the past several months have angered and worried India considerably. Pakistan has, in recent months, attempted to mobilize international opinion against India over human rights violations in Kashmir. The latest attempt was in Geneva at a meeting of the United Nations Commission on Human Rights (UNCHR) in March 1994. While Islamabad's attempts have failed, there is little doubt that Kashmir as a human rights problem is forcing itself onto the attention of the international community.

6. It should be noted at the same time that, from India's point of view, Iran has played a more constructive role in the recent past. At the UNCHR meeting in Geneva, Iran and China got Pakistan to withdraw its resolution on the human rights situation in Kashmir. (Subhas Kirpekar, "Pak Withdraws Kashmir Resolution," Times of India, March 10, 1994.) 
India has responded at two levels. On one, it has toughened its stand. In an unprecedented move on Kashmir, a joint sitting of the two houses of Parliament moved a unanimous resolution repeating India's view that the state was an inalienable part of the Union. At the same time, Home Minister S.B. Chavan reacted sharply in public to foreign involvement in the Kashmir issue, particularly targeting the United States. ${ }^{7}$ On the other hand, India has made Kashmir more accessible to international observers, most recently permitting ten ambassadors from Muslim countries as well as ambassadors of the European Union to visit Kashmir. It has also kept open its offer of a dialogue with Pakistan.

\section{The Limits of India's Strategy}

Since the dismissal of the Faroukh government, Indian governments have come and gone and Kashmir has been run by different governors. Indian strategy, however, has remained largely unaltered. While the army has been used primarily - though not exclusively - to seal the border with Pakistan, paramilitary forces such as the Border Security Force (BSF) and the Central Reserve Police Force (CRPF) have been deployed to contain internal violence. ${ }^{8}$ The purpose of Indian strategy has been to wear down rather than eliminate the insurgents and thereby prepare the ground for political bargaining. This is similar to Indian strategy in the 1960s and 1970s against the various rebels in the Northeast, but while attrition leading to negotiations enjoyed relative success in the Northeast, it is unlikely to work in Kashmir for a variety of reasons.

First, despite the rhetoric of independence, the northeastern insurgents in the end sought greater autonomy and self-rule within the Indian Union. Several of the insurgent groups in Kashmir will not settle for anything so modest; consequently, the room for bargaining appears small. Second, in Kashmir the government is dealing with a multiplicity of groups, whereas in the northeastern states there was usually a clearly identifiable primary insurgent force. Even if the bulk of the JKLF could be persuaded to come to the bargaining table, there is little reason to believe that other Kashmiri groups would follow.

Third, even though there was low-level Chinese support for the insurgents in the Northeast, China had no overweening ethnic, legal, or historical claims in the area and certainly it was not integral to China's self-conception as a nation. Beijing's objectives were two-fold: tie down Indian forces in a low-

7. "US Intentions in Kashmir Suspect: India," Times of India, March 3, 1994, and "Chavan Again Hits Out at US," Times of India, March 5, 1994.

8. For a variety of reasons, the paramilitaries have often proved ineffective, and the army has therefore been called upon to perform "aid to civil" operations with greater frequency. 
cost operation in a strategic arena, and draw attention to the fragility of Indian authority in the region as a way of casting doubt on New Delhi's claims in the Sino-Indian border dispute. In the Kashmir case, Pakistan is a direct party to the conflict and has religious affinities with the predominantly Muslim population in the Valley. Moreover as suggested above, Kashmir is seen as being integral to Pakistan's vision of itself as a nation.

Fourth, quite apart from Pakistan's involvement in, and support to the insurgency, the area is awash in arms. In large part, this floating arms bazaar is a legacy of the Afghan War. Thus, the firepower that the insurgents can bring to bear dwarfs what was available to northeasterners twenty years ago. Moreover, the availability of arms is substantially independent of Pakistani control. Even if Islamabad were to turn off the flow of arms and money, it is likely that the Kashmiri militants would be sufficiently well-supplied to prosecute a costly campaign.

Finally, governments are finding it increasingly difficult to quarantine problems such as Kashmir from international concern. The international community, albeit fitfully and inconsistently, scrutinizes more and more, the human rights records of fellow nations. Indian operations in Kashmir are on view and under scrutiny as they never were in the 1960s and 1970s, setting limits to what can and cannot be done. Two other factors combine to internationalize Kashmir in a way that did not occur with the Northeast. In the West, at least part of the pressure over human rights comes from the activities of Kashmiri immigrants and from sympathizers in the larger Muslim community, South Asian and otherwise. In addition, various Islamic powers such as Iran and Saudi Arabia feel bound to intervene over the status and treatment of Muslims in South Asia and have criticized the Indian government over Kashmir. In sum, Indian counterinsurgency operations must be more restrained than they were in the Northeast; at the same time, the separatists have the capacity to deploy much greater force.

\section{Indian Options in Kashmir}

What, then, are India's options in terms of resolving the Kashmir problem? We can distinguish between seven choices: five unilateral options and two bilateral options involving Pakistan. Unilaterally, India could use force to wear down the militants, reform the administration and politics of the state, hold a plebiscite, re-organize or re-partition the state, or concede Kashmiri independence; bilaterally, it could negotiate with Pakistan, perhaps to include some form of shared sovereignty over Kashmir.

Use of force. The first option is to continue to use force to defeat the militants. Those who favor a military solution in Kashmir suggest that the Indian state can sustain the attendant domestic and international costs, as Kashmir, 


\section{SUMIT GANGULY AND KANTI BAJPAI 411}

within the Indian Union, is a small and peripheral state in terms of economic or political clout. Moreover, external pressure on Kashmir can be contained, whether this is the pressure of international opinion and economic sanctions or military pressure from Pakistan. With India's apparent success in Punjab, there is a growing feeling that New Delhi could "do a Punjab" in the Valley - that is, a more or less purely military solution. However, Kashmir is not Punjab, where the successes have depended heavily on factors beyond the use of force: the fencing of the border with Pakistan and a hospitable terrain for military and police operations; Islamabad's drawing down of support in favor of the Kashmir militancy; and the relatively low level of popular support for secession and militancy in Punjab. These factors are not present in Kashmir.

Reforms. The reform option has three components: refurbish the coercive apparatus of the state, restart Kashmiri politics, and reorder Indian federalism to accommodate Kashmiri demands for greater autonomy. The first component would improve the recruitment, organization, training, and control of India's burgeoning paramilitary forces. As things stand, their poor training coupled with inadequate supervision have led to human rights violations including violence against unarmed citizens. Quite apart from being morally corrosive, such abuses are politically counterproductive. Administrative control over the coercive apparatus of the state, so greatly weakened in recent years, must now be firmly reasserted. The punishment of errant personnel is essential. While the Indian government claims to be disciplining those who have erred, there is a perception that it could do more. ${ }^{9}$

The second part of the reform option would restart the political process within the state. This involves three steps: the release of Kashmiri leaders, talks with the militants, and elections. In late April 1992, the government did release several prominent Kashmiri political leaders, all of whom had been incarcerated for over a year. Militant activity, however, has continued unabated. Thus, a related step must be to negotiate with any militant group willing to hold serious discussions. This will prove difficult; groups such as HUM remain intransigent and intractable, and all groups are fractured and not necessarily under the control of their leaderships. The formation of the Hurriyat and the Jammu and Kashmir Democratic Liberation Front (JKDLF)

9. There are those in India who claim that disciplining army and paramilitary personnel serving in Kashmir would undermine the morale of forces operating under exceedingly difficult circumstances. This view, we feel, betrays a lack of understanding of military forces. A military force that does not punish errant personnel will find its morale declining. The use of violence imposes a burden on individuals. It is overcome in part by the understanding that the use of violence will be controlled and will be exercised only at the command of the proper authorities. A military that breaches this convention will cease to be a disciplined, reliable instrument of force. 
in 1993 appears to be aimed at stopping the fracturing process and at establishing more unified control. If these moves succeed, prospects for a negotiated settlement will grow. ${ }^{10}$

The third step would be to hold elections-also difficult given the fear the militants inspire and the Indian government's perceived record on this score in Kashmir. Difficult or not, New Delhi has little choice. It must keep trying so that it cannot be accused of withholding democracy from Kashmir while practising it elsewhere, but more positively, so that it can draw out of the shadows those in Kashmir, even among the militants, who argue for a "second track," namely, political engagement. The positive aftermath of the Punjab election of 1992, despite its low turnout, should encourage India to repeat the electoral process in Kashmir. In the present circumstances, the government has little option but to demonstrate, over and over, that it will hold fair, safe, and regular elections as mandated by law regardless of threats by the militants. This, incidentally, is important as a token of the government's desire to reinstate the rule of law. It must be matched by better control of the paramilitary forces, but the repeated offer and holding of credible elections would put pressure on the militants to join the challenge of a civil process, especially when the Kashmiri population tires of the violence.

The final component of the reform option would be to restore the federal balance between the center and Kashmir. Kashmiris must be reassured that the governments they elect will be allowed to function as long as they operate constitutionally. A more ambitious option here would be to grant Kashmir far greater autonomy within a revitalized federal polity. This might be accomplished by a new political compact fashioned between the center and the states. A segmented federalism analogous to the British government's Cabinet Mission Plan in 1946 might be plausible, especially in conjunction with a reorganization of states. The plan would have constituted a minimal but strong center-in charge of defense, foreign affairs, currency, and communications-and three tiers of states. Indian federalism is already segmented into three tiers: most states are included in one tier, Kashmir is in the second, and the Union Territories constitute the third. Yet another set of pressures is building on Indian federalism, namely, the reorganization of states as a result of administrative gigantism and remoteness. Under cover of a new federal compact for the nation as a whole, a new relationship with Kashmir and even Punjab might be constructed. The key problem here, clearly, is the fear of opening a veritable Pandora's box of demands.

Plebiscite. In line with its original promise, India could hold a plebiscite to determine the future of Kashmir. By doing so, it would finally redeem an

10. It is unclear at this point how credible the so-called JKDLF is as a party committed to the political process. 
international pledge. Moreover, a plebiscite would be consistent with the logic of democracy (and, one might say, with the logic of the Partition agreement). Finally, the result might not necessarily be negative for the Indian government. ${ }^{11}$ However, there remain troubling questions. Why just a plebiscite in Indian Kashmir? Would Pakistan permit a plebiscite in "Azad Kashmir?" If one or more plebiscites were to be held, who would hold them? India and Pakistan on their respective sides of the Line of Control or an outside agency? More important, to what extent do plebiscites settle matters? Even if a majority of Kashmiris voted for independence or merger with Pakistan, what would be the future of the Hindu and Buddhist areas? Would they be allowed to vote in a subsidiary plebiscite to partition the state? These are not unresolvable issues, but they would be difficult; Partition and post-Partition problems between India and Pakistan attest to this.

Finally, will Indian public opinion allow any government to carry through a plebiscite now or in the foreseeable future? A widespread Indian view is that it will not and that any government seriously committed to such an option will fall. There is no sign that any Indian leader or party today has the courage and persuasive powers to change the public's mind, especially in the wake of Ayodhya and the post-Ayodhya riots all over the Subcontinent. ${ }^{12}$

Reorganize and repartition. There are at least three divisions or parts of Kashmir - the Valley, the Jammu area, and Ladakh. Muslims are dominant in the Valley, Hindus and Sikhs in Jammu, and Shia Muslims and Buddhists in Ladakh. India could divide the state to reflect these demographies. A first option would be to reorganize the state into three states-Kashmir, Jammu, and Ladakh - and to work out a special status for the new Kashmir within India. A more radical option would be to repartition the state and allow only the Valley to secede.

A reorganization of Kashmir is plausible but would not meet the concerns of all the militant groups who would be inflamed further by a vivisection of the state. It is possible that some of the militant groups would not object too strongly to the "partition" of the state along religious lines. They would, of course, insist that the Muslim majority area of western Jammu be included in the Muslim Kashmir state. However, administratively, there would seem to be little advantage in the move: the fish would remain free to move among the loaves. At the same time, Indian leaders would worry that any reorganization of Kashmir might set in motion calls for a reorganization of states in

11. For an argument that the plebiscite would go against Pakistani interests, see Ramesh Khazanchi, "Follies of Plebiscite in Kashmir," Times of India, March 8, 1994.

12. We use the term "public" with reference to an extended attentive public, perhaps the $30 \%$ or less populating a dozen or so urban centers. Even here, the quality of data on attitudes toward, and knowledge of an issue such as Kashmir is uncertain. 
other parts of India, which while administratively attractive and in the long run probably inevitable, would be a political task of stupendous proportions.

If repartitioning to create a new independent Kashmir-comprising say the Valley and Pakistani-occupied Kashmir-was accompanied by voluntary population exchanges, this would seem to offer certain political and administrative advantages. For instance, it would be commensurate with the logic of the Partition. It would leave most of present Kashmir under Indian control, and administratively, what remained in India could be sealed off from militant activity and better integrated. However, the strategic problems thus created would be significant. The primary link to Ladakh is through Srinagar, which is in the Valley and would be lost to the new Kashmir. Alternative passage has improved over the years but remains poor and would involve hazardous territory and climate. Situated between the Valley in the north and the Sialkot District of Pakistan in the south, the strategic position of Jammu would also be extremely vulnerable.

Concede. Another option, theoretically, is to concede the state to Pakistan, or allow Kashmir to exercise "the third option," namely, independence. But to surrender Kashmir would raise fears of an internal domino effect. The departure of Kashmir would strengthen the claims of Sikh militants for a separate Khalistan and very possibly set in motion other disintegrative forces within India. It could also spell the political demise of the government in power. Finally, there is the serious possibility that it would lead to a Hindu backlash against the various Muslim communities in the large northern Indian states where communal feeling is already simmering.

Bilateral negotiations and shared sovereignty. Bilaterally, India could negotiate with Pakistan on a range of issues. India could offer a deal on the Siachen glacier dispute in the northern part of Kashmir, a conflict that has dragged on for the past several years and is costing both sides dearly. Other territorial adjustments might be offered. The Wullar Barrage and Sir Creek disputes might be another area for compromise. In the meantime, New Delhi could continue to pursue confidence-building measures, a process that has been underway since at least 1990 and which has yielded several agreements. In the Simla accords (1972), India and Pakistan agreed that all disputes would be resolved bilaterally and that a final settlement on Kashmir would be discussed between the two sides. India has included such talks among a package of proposals. Pakistan has rejected the proposals and offered counterproposals but in any case has argued that, minimally, a precondition for talks is the drawing down of Indian forces in Kashmir, a position that the Indian government finds it virtually impossible to accept. Both sides continue to exchange proposals and review each other's ideas, but in the immediate future there is little prospect of bilateral talks on a Kashmir settlement. 
A second bilateral option, shared sovereignty, has been suggested as a creative solution to the Kashmir conundrum. ${ }^{13}$ Its chief shortcoming is the lack of precedent in the post-1945 international system, which means there is little to go on in terms of how such an arrangement might work in practice. A number of questions would have to find persuasive answers. For example, would shared sovereignty mean an India-Pakistan condominium over Kashmir extending to all its affairs or only to defense? Would Kashmir be selfgoverning except in respect of defense and external security? Who would be responsible for civil order in the face of disturbances? If India and Pakistan were jointly responsible, how would they mediate differences over their responsibilities? Who, if anyone, would be allowed to settle in a jointly held Kashmir? On what basis would settlement be permitted? Who would be responsible for the collection of revenues and in what measure? Who would assume responsibility for economic development and in what measure?

If and when bilateral talks are held, a preferred Indian option could be to convert the Line of Control in Kashmir into an international boundary. The present LOC would become the de jure border with perhaps certain territorial "adjustments." The advantage to India of this option is to settle the juridical problem over control of present-day Kashmir and to confer legitimacy on its rule. Pakistan's irredentist claim would be ended, and its involvement in the militancy and Kashmiri affairs would be rendered illegal. This would put further pressure on Islamabad's policy of aiding and abetting the militant groups in the Valley. On the other hand, a de jure partition of the state between India and Pakistan would be unlikely to satisfy the militants. Nor would it be any kind of guarantee that arms, money, and people would be altogether stopped from crossing the border even, it must be admitted, if Pakistan was sincerely complicit with the injunctions of international law and formally terminated its aid program.

Both bilateral options-negotiations with Pakistan leading to an easing of external involvement and shared sovereignty-are problematic. First, Islamabad has little incentive to accept either option as a solution as long as the insurgency does not appear fundamentally inimical to Pakistani interests. Second, the various militant groups are unlikely to accept a formal IndiaPakistan partition along the LOC or a condominium on Kashmir. Unhappiness with the Pakistani option, that is, union with Pakistan, is not inconsiderable and may signal a trend. If it continues, and given their capacity for independent action, the militants will resist any arrangements to which they are not party.

13. Ayesha Jalal's remarks at the "South Asia After the Cold War" conference at the Southern Asian Institute, Columbia University, February 1992. B. G. Verghese in India has made a similar suggestion. 


\section{Conclusion}

Each of India's options has drawbacks but some choices are worse or less feasible than others. A combination of the reform and negotiate options are the most tenable, with reform more plausible than bilateral negotiations, given the present state of India-Pakistan relations. The pursuit of a more or less purely military solution is a recipe for further political decay. A plebiscite could well be inconclusive. A reorganization of Kashmir would confer few if any political or administrative advantages over the present situation. Repartitioning Kashmir would be strategically dubious, and converting the LOC into an international border will not end the militancy or necessarily terminate Pakistani involvement in the Valley. Shared sovereignty, while attractive, suffers from the lack of reassuring precedents (though in the long run some form of confederation may be unavoidable). Reform of Kashmir's administration and politics offers the most feasible program. A better paramilitary force under tighter control of civil administration and working within the law, the institution of regular and honest electoral politics, and a decentralization of authority - in short, democracy and federalism - these are the indispensable elements within which a durable solution will emerge. Democracy and federalism do not guarantee a solution to the Kashmir problem, but they have thus far averted in India the kind of vengeful, genocidal wars exemplified by Lebanon and now Yugoslavia. They are the minimal conditions for the emergence of peaceful solutions in South Asia as elsewhere in the new arc of crisis. 